\title{
The Neuquén composite section: magnetostratigraphy and biostratigraphy of the marine lower Jurassic from the Neuquén basin (Argentina)
}

\author{
M.P. Iglesia Llanos $^{\mathrm{a}, *}$, A.C. Riccardi ${ }^{\mathrm{b}}$ \\ a Laboratorio de Paleomagnetismo 'Daniel Valencio', Departamento de Ciencias Geológicas, Universidad de Buenos Aires, Pabellón 2, \\ Ciudad Universitaria, 1428 Buenos Aires, Argentina \\ b Departamento Paleozoología Invertebrados, Museo de La Plata, 1900 La Plata, Argentina
}

Received 3 November 1999; accepted 27 June 2000

\begin{abstract}
Paleomagnetic and biostratigraphic data from five marine sedimentary sections in the Argentine Neuquén basin have allowed to construct the Lower Jurassic Neuquén Composite Section. This composite section comprises 14 reversed and 11 normal polarity Zones, in relation to 17 Andean ammonite Assemblage Zones, spanning the Hettangian-Toarcian (Early Jurassic). It represents the first paleomagnetic data of Lower Jurassic marine successions in the Southern Hemisphere. The Neuquén composite Section was correlated to the International Mesozoic Polarity Time Scale which, for the Lower Jurassic, comprises 54 polarity Zones and 16 Standard ammonite Zones. The correlation between the regional and the international biomagnetostratigraphic scales supports but also refines the correlation between the Andean and Standard ammonite zonations. Correlation between the Neuquén composite Section and the polarity sequences recorded in each section helped to assign several unfossiliferous stratigraphical levels to the corresponding biozones. (C) 2000 Elsevier Science B.V. All rights reserved.
\end{abstract}

Keywords: magnetostratigraphy; biostratigraphy; Neuquen Basin; Jurassic

\section{Introduction}

The Magnetic Polarity Time Scale (MPTS) for post Middle Jurassic times is developed from magnetic anomalies recorded in the oceanic crust (e.g. [1-3]). Older polarity reversals of the Earth's

* Corresponding author. magnetic field must be derived from sections with a detailed chronostratigraphical control, usually based on ammonites Zones, which for the Jurassic typically have a time resolution of $1 \mathrm{Myr}[1,4]$.

Lower Jurassic magnetostratigraphic scales from stratigraphical sections located in the Northern Hemisphere (Fig. 1), mainly in Europe [5-8], were compiled into a Mesozoic MPTS by Ogg $([2,3]$; also [1]). However, magnetic polarities in the MPTS show variability in precision of the age constraints depending on the quality of the biostratigraphic record $[2,3]$.

For the Late Hettangian and Early Sinemurian, 


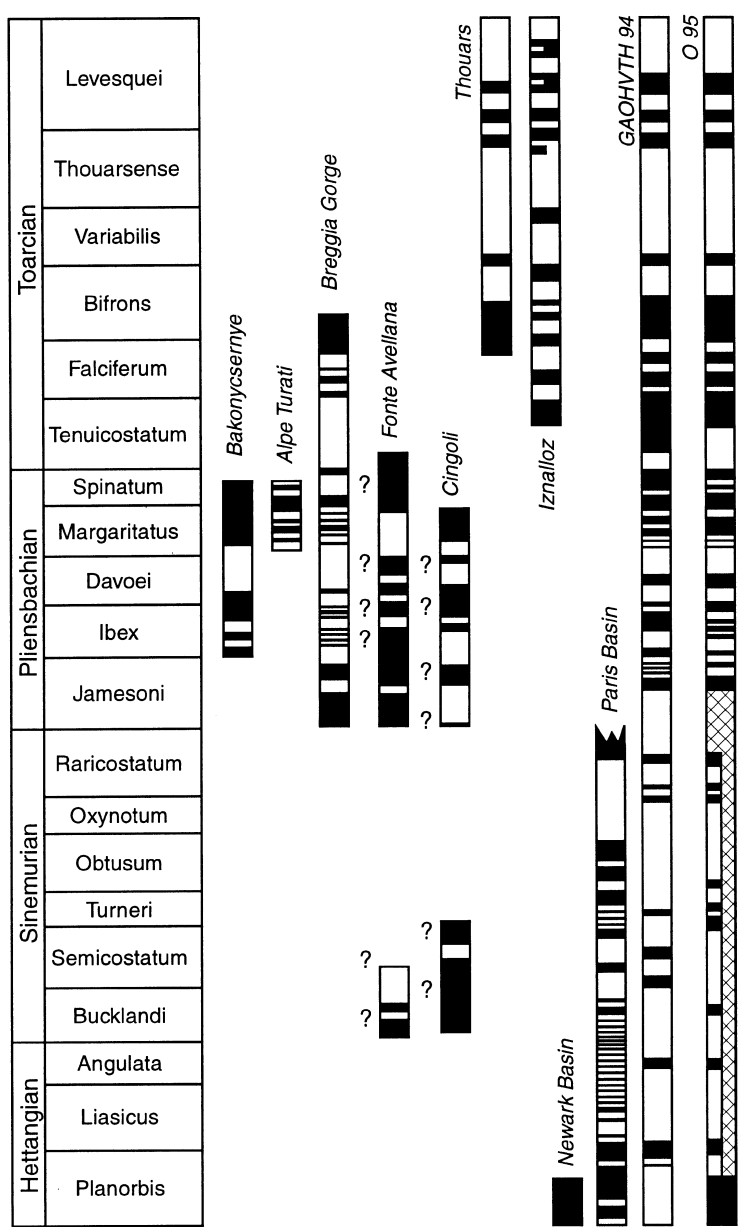

Fig. 1. Other Lower Jurassic magnetostratigraphic sequences. Fonte Avellana: [38]. GAOHVTH 94: [1]; O 95: [2,3].

the MPTS shows a dominant reversed polarity. Ages of polarities were based on the results of one section in Austria, with a poorly represented ammonite zonation [6]. Other magnetostratigraphic studies that were not included in the MPTS were carried out in the lowermost Hettangian of the Newark basin, USA [9,10], and in most of the Hettangian of the Paris Basin [11]. Although none of these sequences yielded ammonites, a dominant normal polarity was interpreted for the Hettangian. Upwards, the uppermost Hettangian and Lower Sinemurian exhibit a dominant reversed polarity with frequent minor normal intervals [11]. The lower part of the Upper Sinemurian, in part controlled by ammonites, de- picts a dominant normal polarity, while the uppermost Sinemurian and lowermost Pliensbachian lack magnetostratigraphic data $[2,3]$.

In most of the Pliensbachian-Toarcian interval, polarity ages are assigned on the basis of studies carried out in Breggia Gorge (Switzerland), Alpi Turati (Italy) [5], Thouars-Airvault (France) [7], Iznalloz (Spain) [8] and Bakonycsernye (Hungary) [12]. In Bakonycsernye, a $9 \mathrm{~m}$ thick section comprises Ammonitico Rosso facies, in which most of the Pliensbachian (Ibex to Spinatum Standard Zones) was recognized [13]. In Breggia Gorge, a ca $100 \mathrm{~m}$ thick section comprises Ammonitico Rosso facies with Pliensbachian (Jamesoni to Spinatum Standard Zones) and Toarcian (Tenuicostatum to Pleydellia aalensis Standard Zones) ammonites [14,15]. In Iznalloz, a $20 \mathrm{~m}$ thick section of Ammonitico Rosso limestones covers the entire Toarcian [8].

In the Aconcagua-Neuquén basin of westerncentral Argentina, or in short, the Neuquén basin, the Lower Jurassic is well represented and biostratigraphic studies have shown a continuous succession (Hettangian to Toarcian) of local ammonite zones $[16,17]$ correlatable to the European Standard Zonation. Thus, the Neuquén basin provides an excellent opportunity to study the Early Jurassic magnetic polarity sequence of sections from outside Europe and in the Southern Hemisphere. Since age constraints throughout are based on ammonites, this study also contributes to refine the correlation between the Andean and European Standard ammonite zonations.

\section{Geological setting and sampling methodology}

The Neuquén basin is a roughly north-south oriented back-arc basin which expands to the southeast [18-20] (Fig. 2). The basin covers more than $16000 \mathrm{~km}^{2}$ and comprises a Mesozoic-Cenozoic sedimentary succession of at least $7 \mathrm{~km}$ thick. It formed due to the extension of Pangea in the Early Mesozoic. Sedimentation began in the Triassic as volcanic and coarse-grained continental deposits, and from the Late Triassic onwards a narrow marine corridor settled in the northern area of the basin. This sea expanded 


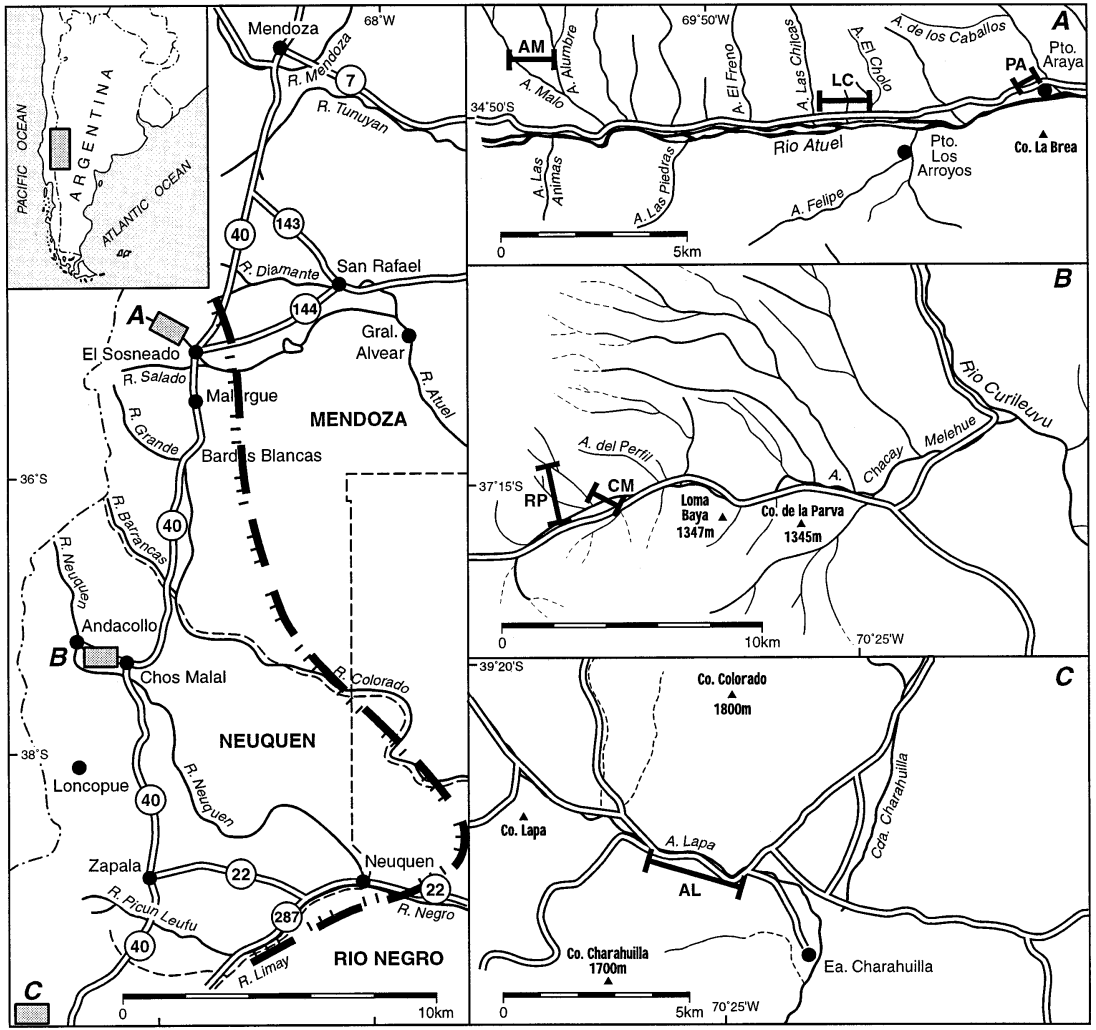

Fig. 2. Geographic location of the Neuquén basin - eastern border in heavy lines - in west Argentina and studied localities. $\mathrm{A}$ : AM, LC and PA, B: RP-CM, and C: AL.

towards the rest of the basin in the PliensbachianToarcian, producing a westwards prograding clastic system and deep basin turbidites, periodically interrupted by volcanic events. Ammonites of the Andean region, present throughout, are especially well represented from west-central Argentina to northern Chile. This ammonite succession has been used to produce a detailed biozonation [21-24] that, even if partly based on endemic East Pacific fauna, is correlatable with the European Standard Zonation and, therefore, provides a precise Hettangian to Toarcian chronology (Fig. 3).

The studied stratigraphical sections are located in the northern, central and southern areas of the Neuquén basin, approximately $250 \mathrm{~km}$ from each other (Fig. 2A,B,C) and belong to north-south oriented anticlines. Tilting of the sections varies from $20^{\circ}$ in Arroyo Lapa (AL) to $60^{\circ}$ in Arroyo Malo (AM). Major deformation of the area re- sulted from the Andean orogeny (Late Cretaceous-Tertiary).

In the north (Fig. 2A) a ca 2000 m thick succession crops out, which is mainly composed of Upper Triassic-Pliensbachian marine sediments, belonging to the AM, El Freno (EF) and Puesto Araya (PA) formations (FM.) (Fig. 4). The AM Fm. consists of ca $300 \mathrm{~m}$ of shales and finegrained sandstones bearing Late Triassic to Early Hettangian ammonites [25]. The overlying EF Fm. is composed of conglomerates and coarsegrained sandstones assigned to the HettangianSinemurian [16]. At the top of the succession, the PA Fm. is made up mainly of sandstones and limestones which increase in grain size and thickness towards the east where it yields Pliensbachian ammonites.

In AM and Las Chilcas (LC) sections, the sampled interval corresponding to EF and PA FMs. is $1450 \mathrm{~m}$ thick (Fig. 4). In these sections, 


\begin{tabular}{|c|c|c|c|c|}
\hline \multicolumn{3}{|c|}{ STANDARD ZONATION } & \multicolumn{2}{|c|}{ NEUQUEN BASIN } \\
\hline \multicolumn{2}{|c|}{ STAGES } & ZONES & ASSEMBLAGE $Z$ & NES \\
\hline \multirow{8}{*}{ 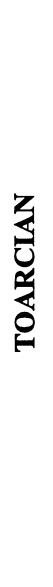 } & \multirow{3}{*}{$\mathrm{U}$} & \multirow{2}{*}{ LEVESQUEI } & Dumortieria & $\mathrm{Z} 20$ \\
\hline & & & $\begin{array}{l}\text { Phlyseogrammoceras } \\
\text { (?) tenuicostatum }\end{array}$ & Z19 \\
\hline & & THOUARSENSE & Phymatoceras & Z18 \\
\hline & \multirow{3}{*}{ M } & VARIABILIS & Collina chilensis & $\mathrm{Z} 17$ \\
\hline & & \multirow[t]{2}{*}{ BIFRONS } & Peronoceras pacificum & $\mathrm{Z} 16$ \\
\hline & & & Peronoceras largaense & $\mathrm{Z} 15$ \\
\hline & & FALCIFERUM & $\begin{array}{l}\text { Dactylioceras } \\
\text { hoelderi }\end{array}$ & $\mathrm{Z} 14$ \\
\hline & & TENUICOSTATUM & Tenuicostatum & $\mathrm{Z} 13$ \\
\hline \multirow{6}{*}{ 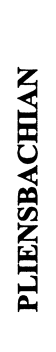 } & \multirow{2}{*}{$\mathrm{U}$} & SPINATUM & $\begin{array}{c}\text { Fanninoceras } \\
\text { disciforme }\end{array}$ & $\mathrm{Z} 12$ \\
\hline & & MARGARITATUS & \multirow{2}{*}{$\begin{array}{c}\text { Fanninoceras } \\
\text { fannini } \\
\text { Fanninoceras } \\
\text { behrendseni }\end{array}$} & $\mathrm{Z} 11$ \\
\hline & \multirow{4}{*}{$\mathrm{L}$} & DAVOEI & & Z10 \\
\hline & & \multirow{2}{*}{ IBEX } & Dubariceras & Z9 \\
\hline & & & Tropidoceras & $\mathrm{Z} 8$ \\
\hline & & JAMESONI & Miltoceras & $\mathrm{Z7}$ \\
\hline \multirow{6}{*}{ 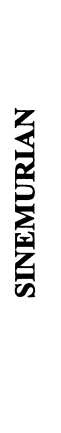 } & \multirow{3}{*}{$\mathrm{U}$} & RARICOSTATUM & \multirow{4}{*}{ "Epophioceras" } & \multirow{4}{*}{ Z6 } \\
\hline & & OXYNOTUM & & \\
\hline & & OBTUSUM & & \\
\hline & \multirow{3}{*}{$\mathrm{L}$} & TURNERI & & \\
\hline & & SEMICOSTATUM & "Agassiceras" & Z5 \\
\hline & & BUCKLANDI & "Vermiceras" & $\mathrm{Z4}$ \\
\hline \multirow{4}{*}{ 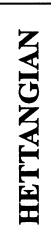 } & $\mathrm{U}$ & ANGULATA & \multirow{2}{*}{$\begin{array}{c}\text { "Waehneroceras- } \\
\text { Schlotheimia" }\end{array}$} & \multirow{2}{*}{ Z2 } \\
\hline & M & LIASICUS & & \\
\hline & & & "Psiloceras" & $\mathrm{Z1}$ \\
\hline & $\mathrm{L}$ & PLANORBIS & & \\
\hline
\end{tabular}

Fig. 3. Correlation between the Andean (eastern Pacific) and Standard International ammonite Assemblage Zones. mudstones, claystones and sandstones with subordinate limestones and conglomerates, depict turbiditic and basinal to off-shore facies. To the east, the sampled interval in the PA section comprising the EF and PA FMs, is $400 \mathrm{~m}$ thick (Fig. 4). This section depicts fluvial-alluvial to near-shore facies.

In the central area of the Neuquén basin (Fig. 2B), the Rajapalo (RP)-Chacay Melehue (CM) section consists of a ca $500 \mathrm{~m}$ thick succession with volcanic rocks lying conformably over a pre-Jurassic? basement, followed by tuffs, volcanics and sandstones of the Lista Blanca (LB) Fm., and the black shales of the Los Molles (LM) Fm. (Fig. 5). The LB and LM FMs indicate marginal marine to off-shore facies.

In the south (Fig. 2C), the AL section is a $480 \mathrm{~m}$ thick which comprise the Lapa and LM FMs (Fig. 5). The sampled interval of the Lapa Fm. is made up of tuffs assigned to the Upper Triassic or lowermost Jurassic [18], whilst that of the overlying LM Fm., of ammonite-bearing sandstones and mudstones from outer shelf facies.

Paleomagnetic sampling levels in these sections were selected on the basis of suitable lithologies and distribution of biostratigraphic levels, with a mean sampling distance of $10 \mathrm{~m}$, well within the range of ammonite biozones. Approximately 700 oriented hand samples were collected, distributed over 190 sampling stratigraphical levels.

\section{Biostratigraphy}

Assignment of ammonites to Standard Zones or to Andean Assemblage Zones and their correlation, is based on an exhaustive study of widely distributed fauna. The accuracy in identifying biozones in a single section or the same biozone in different sections is quite variable. This situation is further complicated when sequences with different biostratigraphic schemes (i.e. Europe and southern South America) are compared. Biostratigraphic correlation must thus be improved by using additional stratigraphical methods, like magnetostratigraphy.

The biozonal succession used in this paper [22] includes, in some cases, an Assemblage Zone with 

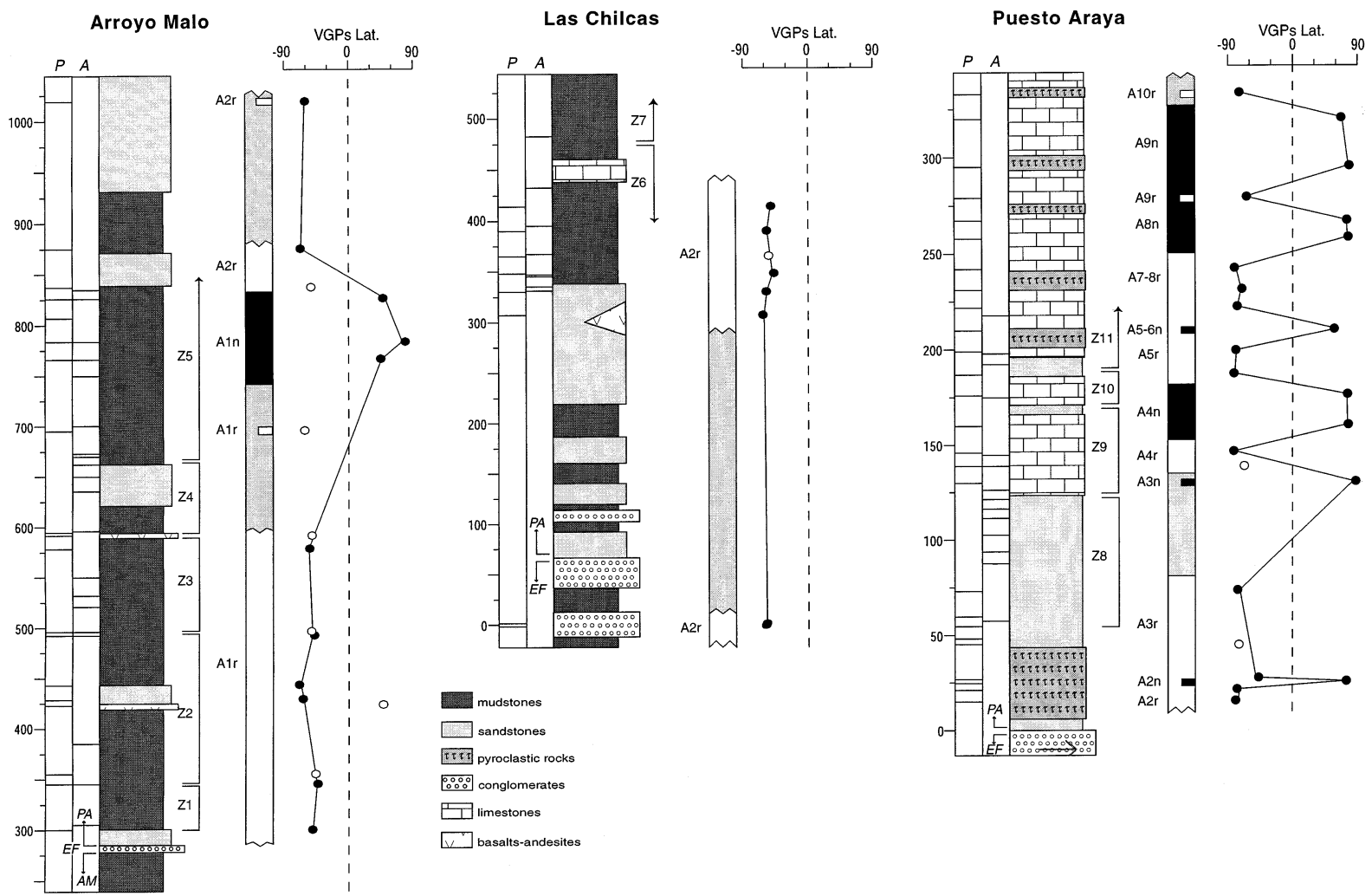

Fig. 4. AM (Hettangian to Sinemurian), LC (Sinemurian) and PA (Pliensbachian) sections. On the left, meters from the base, location of paleomagnetic sampling sites $(P)$ and ammonites levels $(A)$; on the right, ' $\mathrm{Z} n$ ' indicates the range of ammonite Assemblage Zones described in Fig. 3 and A1-14 n/r the corresponding polarity Zone.

names that are under revision (Fig. 3). Studies in progress may result in changes in fossil taxonomy, whose eventual significance for biostratigraphy is mentioned below.

In western Argentina, Hettangian and Sinemurian ammonite bearing strata are only known from the northern margin of Río Atuel, and most studied fauna come therefore from the AM and LC sections (Fig. 2A). In the AM, the first Hettangian ammonites belong to different species of Psiloceras Hyatt [16] and were used to define the 'Psiloceras' Assemblage Zone (Z1) from level 300 to $345 \mathrm{~m}$. New findings indicate that these ammonites are most probably equivalent to those placed by von Hillebrandt et al. [24] at the boundary between the Planorbis and Liasicus Standard Zones. From level 345 to ca $500 \mathrm{~m}$, ammonites characterize several schloteiimidae taxa and on that basis are included in the 'Waehneroceras-
Schlotheimia' Assemblage Zone (Z2). They are considered equivalent to part of the Liasicus and Angulata Standard Zones. From level 500 to 670 $\mathrm{m}$, the Badouxia canadensis (Z3) and 'Vermiceras' Assemblage Zones (Z4)b are represented, with ammonites of the Andean region that correspond to the Alsatitinae (see $[16,26]$ ). These correlate with the Marmorea Zone of the northern Alps and, therefore, with the uppermost Angulata and lowermost Bucklandi Zones of the Standard Zonation (Fig. 3). From level 670 to 840 m, Early Sinemurian arietitids, usually of relatively large size, are included in the 'Agassiceras' Assemblage Zone (Z5). Ammonites are considered equivalent to those of the Bucklandi [26] and/or the Semicostatum [16,17] Standard Zones (Fig. 3).

The Upper Sinemurian is represented at Arroyo LC (Fig. 4). In this section, the first interval of fossiliferous levels (from level 300 to $450 \mathrm{~m}$ ), com- 

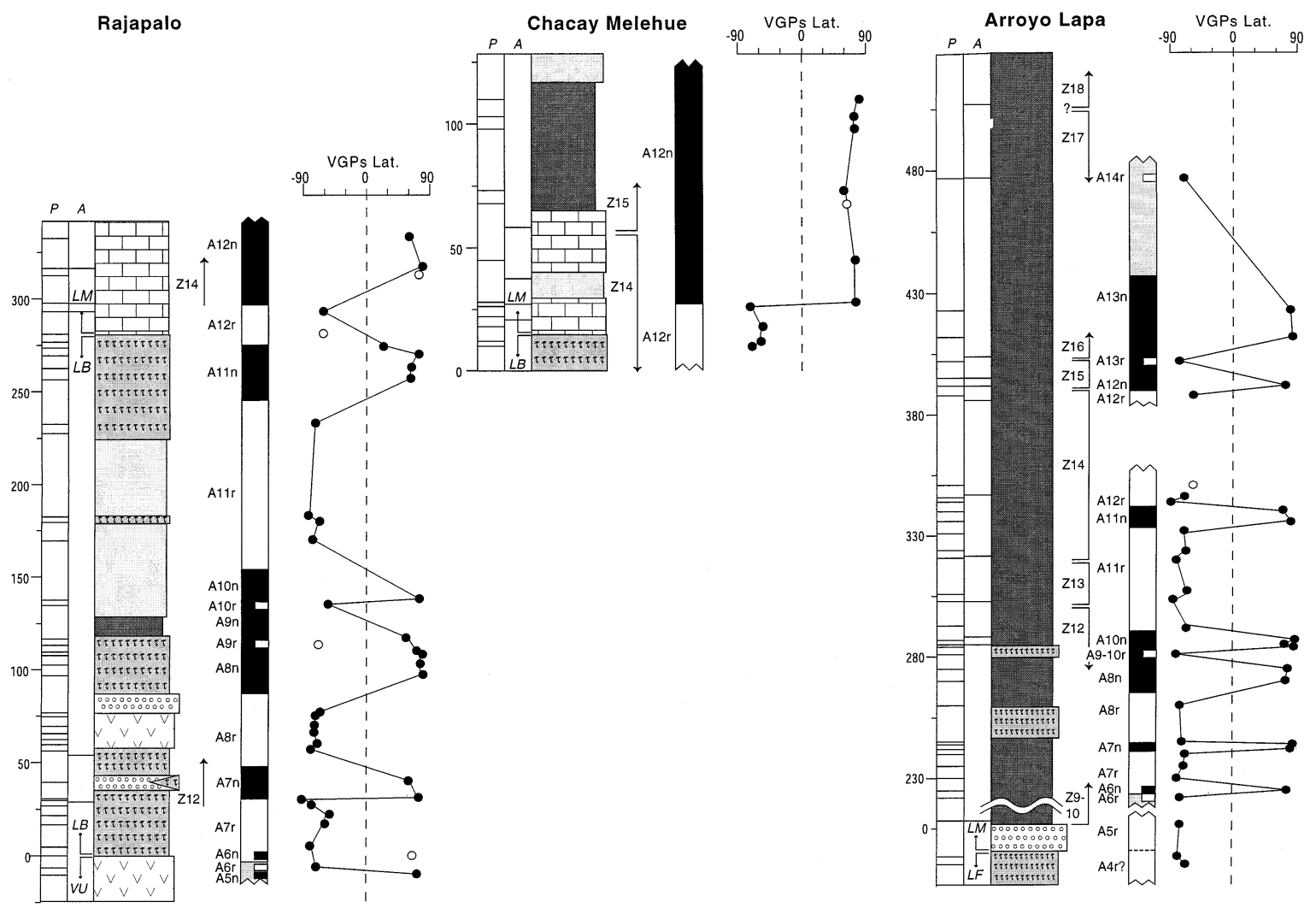

Fig. 5. RP, CM and AL sections (Pliensbachian-Toarcian). References as in Fig. 4. VU: Volcanic unit (unnamed).

prises late Sinemurian echioceratids and is placed in an 'Epophioceras' Assemblage Zone (Z6). Ammonites correspond to the Turneri to Raricostatum Zones (Fig. 3).

Early Pliensbachian ammonites are well represented in the upper part of the LC and the PA sections (Fig. 4). The first Pliensbachian fossiliferous levels are represented in LC from level $475 \mathrm{~m}$, where they overly the Z6 Zone. They are characterized by eoderoceratids, i.e. the Miltoceras or Apoderoceras-Eoderoceras Assemblage Zone (Z7) $[16,21,22]$, which is correlated with the Jamesoni Standard Zone. In the PA section, the first ammonite fauna is represented from level 50 to 120 $\mathrm{m}$, and has been included in a Tropidoceras Assemblage Zone (Z8) [21] (Fig. 4). It correlates with the uppermost Jamesoni and lower Ibex Standard Zones. From level 120 to $170 \mathrm{~m}$, ammonites represent the Dubariceras Assemblage Zone (Z9) [16,17,22]. This correlates with the
Ibex and lowermost Davoei European Zones (Fig. 3). The following Fanninoceras behrendseni Assemblage Zone (Z10) is widespread in centralwest Argentina and central Patagonia. It is represented in the PA section, from level 170 to $190 \mathrm{~m}$, as well as in the base of the AL section (Figs. 4 and 5). Z10 has been correlated with the upper part of the Davoei Standard Zone. The following zone of the Andean Pliensbachian is the Fanninoceras fannini Assemblage Zone (Z11) which is represented from level 190 to $220 \mathrm{~m}$ in PA (Fig. 4). It is considered equivalent to the uppermost Davoei and lowermost Margaritatus Sandard Zones. The following Fanninoceras disciforme Assemblage Zone (Z12), is represented in the RP section from at least level 25 to $50 \mathrm{~m}$ and in $\mathrm{AL}$ from level 280 to $300 \mathrm{~m}$ (Fig. 5.). Z12 has been considered equivalent to the upper Margaritatus and Spinatum Standard Zones.

Toarcian strata are also quite widespread in the 

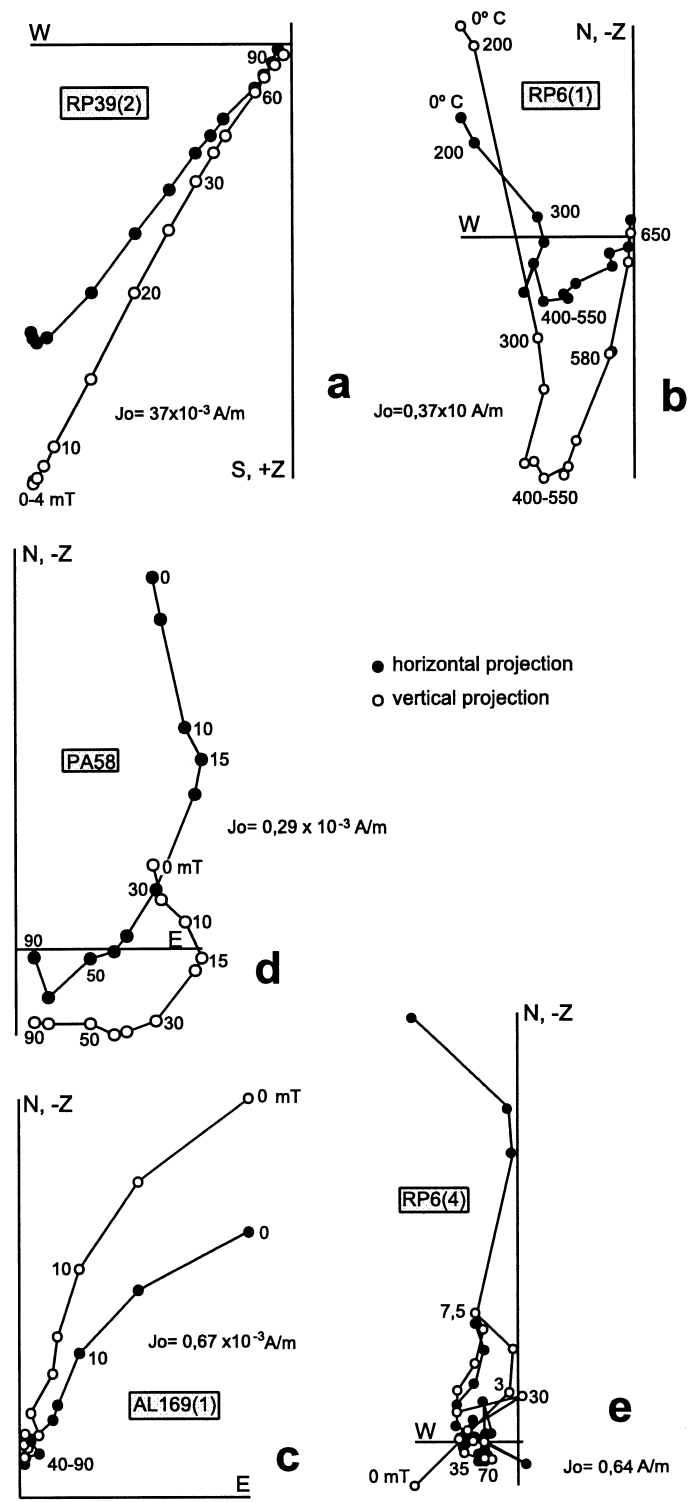

Fig. 6. Orthogonal plots showing bedding corrected type AE specimens; (a) type A specimen collected at $S 16$ in the $\mathrm{RP}-\mathrm{CM}$ section, (b) type B specimen, collected at S14 in the $\mathrm{RP}-\mathrm{CM}$ section, (c) type $\mathrm{C}$ specimen, collected at $S 80$ in $\mathrm{AL}$ section, (d) type $D$ specimen collected at $S 20$ in PA section, and (e) type E specimen collected at $S 14$ in the RP-CM section. $J_{0}=$ natural remanent magnetization $(\mathrm{A} / \mathrm{m})$.

Neuquén basin, where they are usually represented by outer shelf and basinal calcareous shales; they are represented in the RP-CM and Al sections (Fig. 5). Ammonites from the Tenui- costatum Standard Zone (Z13) [27] have been recorded in the AL section from level 300 to $320 \mathrm{~m}$ and equivalent beds may exist in RP as well (from level 150 to ca $225 \mathrm{~m}$ ), although here ammonites have not been found yet. The following Dactylioceras hoelderi Assemblage Zone (Z14) is correlated with the Falciferum Standard Zone (Fig. $3)$. It is represented In RP-CM sections, from level 300 and $37 \mathrm{~m}$ respectively, and in the $\mathrm{Al}$ section from level 320 to $390 \mathrm{~m}$ (Fig. 5). The subsequent interval in both sections, approximately $20 \mathrm{~m}$ thick, includes the Peronoceras largaense Assemblage Zone (Z15), which is considered equivalent to the lower part of the Bifrons Standard Zone. The following Peronoceras pacificum Assemblage Zone (Z16) has only been documented from one level in Al (level 405 m; Fig. 5). This biozone has been correlated with the middle part of the Bifrons Standard Zone. The next two fossiliferous levels in the AL section contain ammonites of the Collina chilensis (Z17) (level $478 \mathrm{~m}$ ) and Phymatoceras (Z18) (level $506 \mathrm{~m}$ ) Assemblage Zones, which have been correlated with the upper Bifrons-lower Variabilis and upper Variabilis and Thouarsense Standard Zones, respectively. The youngest Toarcian ammonites in the Andes belong in the Phlyseogrammoceras? tenuicostatum (Z19) and Dumortieria Assemblage Zones (Z20) and are correlated with the Levesquei Standard Zone but so far more data are necessary to complete the biomagnetostratigraphic study of these levels.

\section{Demagnetization techniques and paleomagnetic results}

In general, two standard cylindrical specimens ( $2.5 \mathrm{~cm}$ long) were drilled from each hand sample. Routine demagnetization procedures and analysis were performed at the Laboratorio de Paleomagnetismo 'Daniel Valencio', Universidad de Buenos Aires. Both alternating fields (AF) and high temperatures $(\mathrm{TH})$ were carried out using a $2 \mathrm{G}$ AF demagnetizer and a Schoenstedt furnace. Remanent magnetizations were measured mostly in a 2G DC SQUID magnetometer; Schoenstedt, Digico and UBA $8 \mathrm{~Hz}$ [28] spinner magneto- 

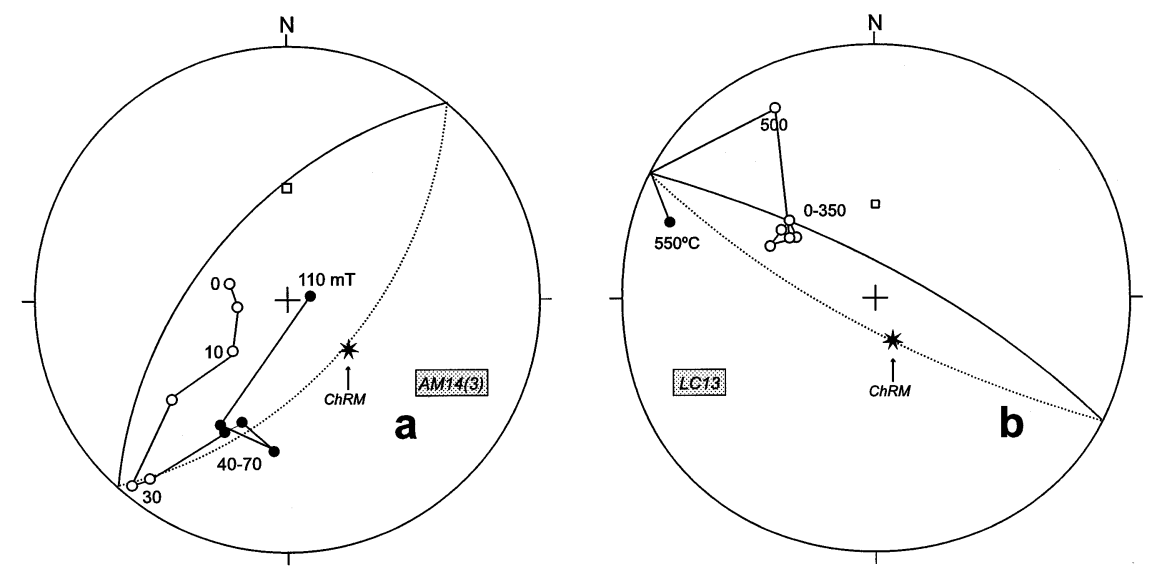

Fig. 7. Polarities of specimens with remagnetization circles were reliable when (a) a change towards positive inclinations (reversed) occurred before the last step - AM14(3), S7 in the AM section; Fig. 4 -, and 'probable' when (b) the change in the inclination produced only in the last step -LC13, S7 in the LC section; Fig. 4. Equal angle projections.

meters were also employed. As a rule, specimens were demagnetized in approximately $10 \mathrm{AF}$ steps usually up to 60-90 mT and occasionally $130 \mathrm{mT}$; thermal demagnetization was done up to temperatures of $550-580^{\circ} \mathrm{C}$ and sometimes $730^{\circ} \mathrm{C}$. Susceptibility was monitored after each heating step in order to detect possible changes in the magnetic mineralogy. Magnetic components were determined using principal component analysis [29].

Analysis of magnetic components was done using stereographic and orthogonal demagnetization plots. On the basis of mainly thermal demagnetization curves, the characteristic remanent magnetization (ChRM) was interpreted to be carried mainly by minerals of the titanomagnetite series and subordinately, by titanohematite. The widespread presence of titanomagnetite is consistent with the volcanic activity that was taking place in the source area to the west. Thin sections from basaltic lava flows (at level $65 \mathrm{~m}$ in RP, Fig. 5) shows skeletal titanomagnetite that was formed due to the rapid cooling of the lava flows as they flowed into the sea. Titanomagnetite as well as titanohematite could also be identified through microprobe studies.

The paleomagnetic analysis showed five main types, each with different reliabilities of the ChRM (Fig. 6). Among these types, the most reliable were those carrying only the ChRM (type
A), occasionally with a removable $\left(400-450^{\circ} \mathrm{C}\right)$ secondary magnetic component (type B), and those whose defined ChRM could not be completely demagnetized in AF fields (type C) - likely carried by titanohematite. ChRM of type $\mathrm{C}$ specimens were analyzed using Fisherian statistics [30]. A less reliable type showed two overlapping magnetic components thus showing demagnetization trajectories that do not go to the origin (type D); it was analyzed using statistical methods of remagnetization circles [31,32]. Finally, specimens with the least reliable paleomagnetic behavior were discarded (type E). From all the specimens processed, an average of $20-30 \%$ per section were discarded for showing unreliable paleomagnetic behavior (Fig. 6e) or present-day field directions likely induced by recent weathering.

Virtual geomagnetic poles (VGPs) in the Lower Jurassic sequence were determined in 115 stratigraphical most levels with number of specimens $(n) \geq 3$ (Figs. 4 and 5). Polarities on the other hand, were also determined in some levels with

Fig. 8. On the left side of the columns, names of the sections - Río Atuel - and meters from the base. The Lower Jurassic Neuquén composite section depicts polarity Zones (A1-14 n/r) and ammonite Assemblage Zones (Zn). Z1-3: Hettangian; Z4-6: Sinemurian; Z7-12: Pliensbachian; Z13-20: Toarcian. 


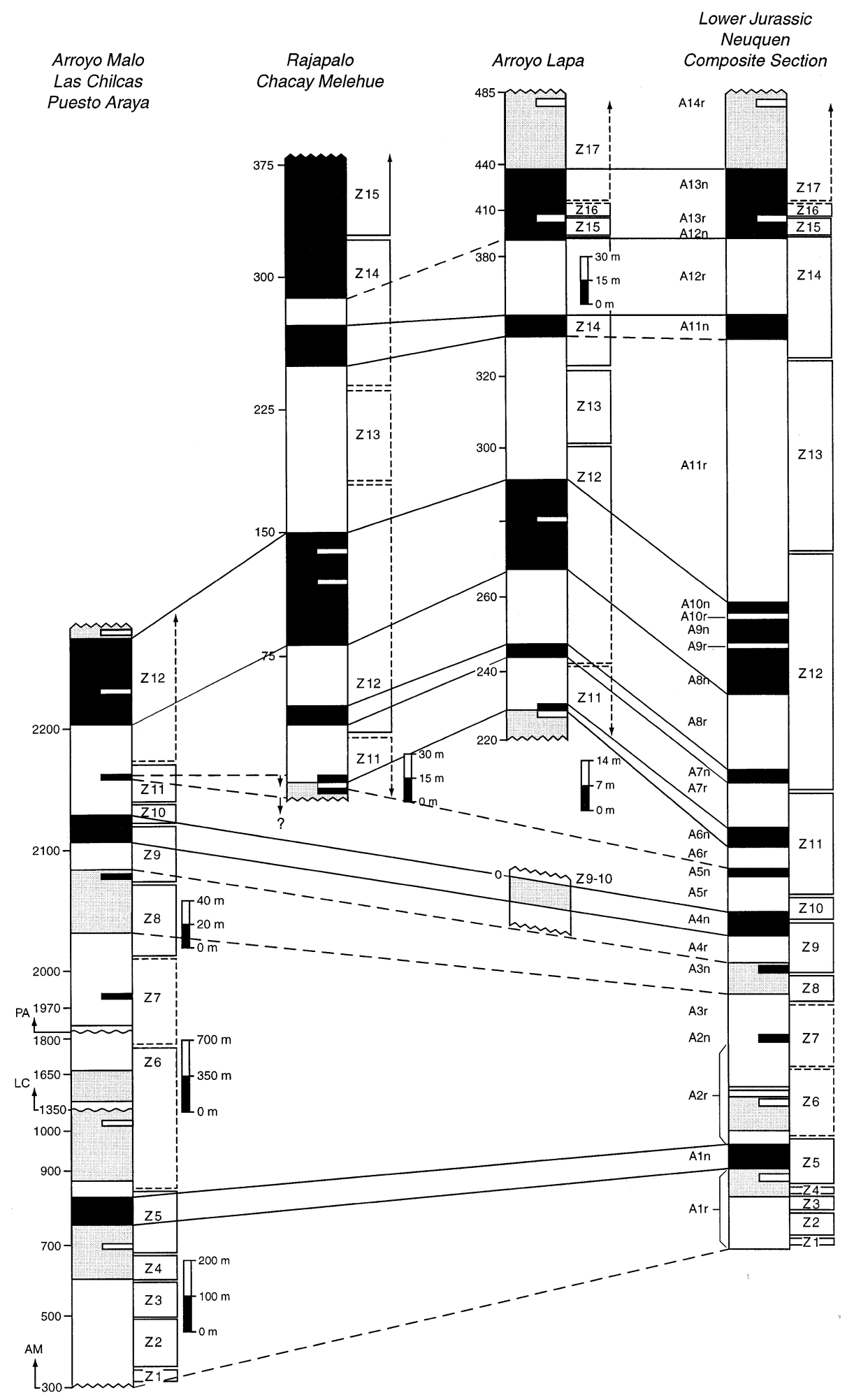



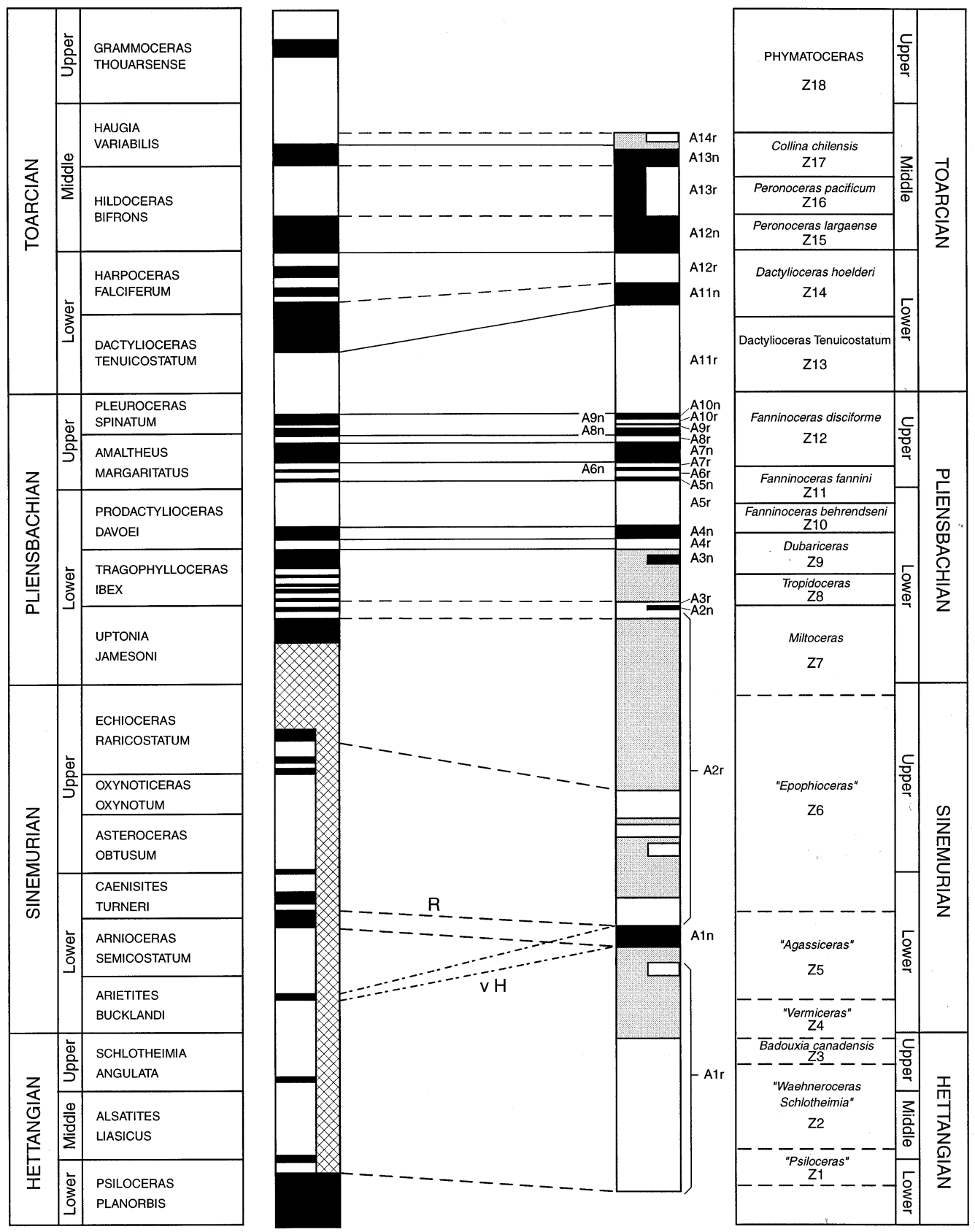

Fig. 9. Correlation between the Neuquén composite section and the MPTS [2,3]. There are two proposals for the correlation of the Z5 Zone with the Standard Zonation, one (vH) according to von Hillebrandt [26] and the other (R) according to Riccardi [16]. 
two specimens only (see tables $1-5$ in the EPSL Online Background Dataset ${ }^{1}$ ). The primary origin of the isolated magnetizations was tested by several paleomagnetic field tests and complementary studies.

The reliability of polarities is derived from the type of specimen found in the site. The polarity from stratigraphical levels with at least one specimen with well defined directions of ChRM was considered as most reliable, while polarities derived from remagnetization circles were only considered reliable if demagnetization paths showed a clear shift towards positive (reversed) inclinations, in at least the two last steps (Fig. 7a). If the shift towards positive inclinations occurred just in the last demagnetization step (Fig. 7b), the assigned reversed polarity was 'probable' (half column in Figs. 4 and 5). On the other hand, if demagnetization paths showed only negative inclinations, polarities were 'uncertain', because of the difficulty in distinguishing a Jurassic normal polarity component from one caused by a present-day overprint.

\subsection{Hettangian-Sinemurian}

In the Hettangian-Sinemurian AM and LC sections, the ChRM is mainly reversed and interpreted to be carried mainly by titanomagnetite. Mean site directions (see tables 1 and 2 in the EPSL Online Background Dataset ${ }^{1}$ ) passed the statistical fold test [33], indicating that the ChRM was acquired before the Andean orogeny. In the AM section, the statistical reversal test [34] was 'indeterminate' because of the small number of normal directions.

The sedimentary succession in AM and LC is intruded by andesitic sills. The sill at level $430 \mathrm{~m}$ in AM carried a normal polarity ChRM that was also recognized in the host sediments of the neighboring stratigraphical levels as a partial overprint (Fig. 4). Another sill at level $590 \mathrm{~m}$ in AM carried a reversed polarity ChRM instead. Since the intrusion may have taken place at a different time -

\footnotetext{
${ }^{1}$ http://www.elsevier.nl/locate/epsl, mirrorsite: http://www. elsevier.com/locate.epsl
}

different polarity - during the Sinemurian, the results were not included in the magnetostratigraphy of the AM section.

\subsection{Pliensbachian-Toarcian}

The studied sections of Pliensbachian-Toarcian age are located in the northern, central and southern (Fig. 1A,B,C) areas of the basin. Lithologies are coarse-grained sediments and volcanics, of shallow marine facies. The ChRM in the Pliensbachian-Toarcian succession shows similar numbers of reversed and normal polarities (Figs. 4 and 5).

Mean site directions in the Pliensbachian-Toarcian successions (see tables 3-5 in the EPSL Online Background Dataset ${ }^{1}$ ) pass the following field tests and complementary studies: (i) the fold test performed among the PA, RP-CM and AL sections [33], (ii) reversal tests class ' $\mathrm{B}$ ' [34], (iii) a conglomerate test in RP (at level $80 \mathrm{~m}$ ) using the randomness directions test [35] (number of clasts $=32$, critical test value $=11$, test value $=5.9$ ), (iv) the ChRM of a clast from a basaltic breccia in RP proved to be carried by the same mineral as in the basaltic matrix and lava flows but with a different direction, indicating that the lavas were not remagnetized, and (v) isothermal remanent magnetization studies of the lava flows in RP proved that the remanence was carried mainly by titanomagnetite, while optical analysis revealed this mineral was primary skeletal; also microprobe studies confirmed the existence of this magnetic mineral as well as titanohematite.

\section{Magnetostratigraphy of the lower Jurassic Neuquén composite section}

In the magnetostratigraphic sequences, polarities with a single datum - determined from a single stratigraphical level - are displayed as half columns. The polarity zones are represented in the composite magnetostratigraphy (Fig. 8) by the letter 'A' from Aconcagua-Neuquén basin, followed by the number of the corresponding polarity recorded from base to top and by ' $\mathrm{n}$ ' or ' $\mathrm{r}$ ' for polarity. 
In the Lower Hettangian-Lower Sinemurian AM section, the A1r polarity zone was recorded from Z1 to part of Z5, followed by A1n and A2r. In the Sinemurian LC section, only the A2r polarity zone was recorded in $\mathrm{Z6}$ and in the underlying unfossiliferous interval (Fig. 4).

The Pliensbachian-Toarcian biomagnetostratigraphy resulted from combining the data from the PA, RP-CM and AL sections (Figs. 4 and 5). Thus, in the PA section, the A2r to A3r polarity zones were recorded (Z7?), extending upwards into $\mathrm{Z} 8$, and with the following zone A3n extending into $\mathrm{Z} 9, \mathrm{~A} 4 \mathrm{r}$ and $\mathrm{A} 4 \mathrm{n}$ extending into $\mathrm{Z10}, \mathrm{A} 5 \mathrm{r}$ extending into $\mathrm{Z} 11$, up to A10r. In the RP-CM section, A5n to A7r polarity zones were recorded in the lower unfossiliferous interval, extending into Z12 with $\mathrm{A} 7 \mathrm{n}$ and $\mathrm{A} 8 \mathrm{r}$, and upwards to $\mathrm{A} 12 \mathrm{r}$ and $\mathrm{A} 12 \mathrm{n}$ in $\mathrm{Z} 14$. In the $\mathrm{AL}$ section, the A4r? polarity zone was recorded at the top of the unfossiliferous Lapa Fm., followed by A5r to A6n in $\mathrm{Z} 9-10, \mathrm{~A} 7 \mathrm{r}$ to A8n extending into $\mathrm{Z} 12$ up to A11r and extending to Z14; in this biozone, polarities follow up to A12n, extending into Z15, A13r? extending into Z16, and up to A14r extending into Z17.

The resulting Neuquén composite section spanning the Hettangian-Middle Toarcian comprises 14 reversed (A1r-A14r) and 13 normal (A1nA13n) polarity Zones associated with 16 ammonite Assemblage Zones. These Zones correlate in turn with 54 polarity Zones related to 17 Standard ammonite Zones in the MPTS [2] (Fig. 9). We consider, however, that some polarities in the Neuquén composite Section are probably missing due to the large gaps in the sampling intervals.

A significant concern in comparing pre-Middle Jurassic magnetostratigraphic scales is that the reliability of correlation depends strongly on the quality of both the magnetostratigraphic and the paleontological record. In the case of the Neuquén composite section, the most reliable correlations are achieved in the Pliensbachian (Z8-Z12), whereas a less reliable correlation is found in the Hettangian-Sinemurian and Middle Toarcian (Fig. 9).

The resultant magnetostratigraphy aids in estimating the probable range of a biozone if no fos- sils could be found (e.g. Z11 in the RP-CM section).

\section{Correlation between the Neuquén composite section and the MPTS}

When comparing the Neuquén composite and the MPTS, it appears that there are major differences in the Lower-Middle Hettangian, the Sinemurian and the Lower Toarcian (Fig. 9).

\subsection{Hettangian}

The Lower Hettangian Planorbis Zone is represented mostly within a normal magnetic polarity, followed upwards by a dominant reversed interval that extends into the Liasicus Zone. This is in part consistent with data provided by Posen et al. [36], based on one section with ammonites, recording a single normal polarity for the Planorbis Zone. Other studies not dated with ammonites also represent a dominant reversed polarity in the Hettangian-Sinemurian boundary [11,37]. In the Neuquén basin, the polarity recorded for the Hettangian and part of the Lower Sinemurian (Z1 to part of the Z5 Zones) is entirely reversed (A1r). Thus, in the magnetostratigraphic correlation proposed, the Z1 Zone should be placed at the Lower-Middle Hettangian boundary and therefore, the normal polarity represented in the MPTS might be disregarded, unless correlation of the Z1 Zone is with the base of the Liasicus Zone. Upwards, the sector of A1r recorded in the Z2 Zone is correlated with the Liasicus to Middle Angulata Zones. The part of A1r recorded in the Z3 Zone can be correlated with the Upper Angulata Zone.

\subsection{Sinemurian}

So far, the Z5 Zone remains controversial in its possible equivalence in the Standard Zonation. According to von Hillebrandt [26], the represented horizons of the Z5 Zone in the AM section are correlatable with the Bucklandi Zone and therefore, the top of A1r should be at least in part equivalent to the lower Bucklandi, A1n to 
the middle Bucklandi, and the base of A2r to the upper Bucklandi Zone. On the other hand, Riccardi [16] argues that those levels extends up to the Semicostatum Zone. In that case, the Hettangian-Sinemurian interval in the MPTS should be moved downwards until at least the Semicostatum-Turneri boundary is reversed, coinciding with the lowermost part of A2r. Upwards, the middle part of A2r in the Z6 Zone could be correlated with the Turneri to Obtusum Zones, and with the upper Oxynotum-lower Raricostatum Zones.

\subsection{Pliensbachian}

Upwards, the Z7 Zone would be represented by uppermost A2r, A2n and part of A3r, which can be correlated with the top of the Jamesoni Zone. The upper part of A3r in the Z8 Zone is then correlated with the Jamesoni-Ibex boundary. The exact equivalence to the MPTS, for the Hettangian-Lower Pliensbachian interval however, requires additional paleomagnetic data. The following Z9 Zone, represented by A3n, A4r and $\mathrm{A} 4 \mathrm{n}$ is correlated with the upper Ibex and lower Davoei Zones, while A4n to part of A11r are correlated with the Davoei to part of the Tenuicostatum Zones.

\subsection{Toarcian}

In the Toarcian, Ogg [2] notes that correlations of polarity Zones between the Toarcian sections at Breggia Gorge [5] and Iznalloz [8] were difficult to establish, because of stratigraphical discontinuities and regional differences among the sections. Thus, in Breggia Gorge, the Tenuicostatum Zone plus the base of the following Falciferum Zone depict only reversed polarity, whereas in Iznalloz the same interval includes a normal polarity interval as well (Fig. 1). In the Neuquén basin, the Tenuicostatum Zone is represented only in the AL section (Fig. 8) by A11r. Therefore, we conclude that the Tenuicostatum Zone plus the base of the Falciferum Zone are in a single reversed polarity Zone, which implies a revision of the MPTS. This is followed by a normal polarity Zone (A11n) and a reversed polarity Zone
(A12r) which fall within the Z14 Zone. The base of A12n coincides approximately with the Falciferum-Bifrons boundary. A12n almost encompasses the entire Z15 Zone, which correlates with the uppermost Falciferum Zone and lower half of the Bifrons Zones, A13r? includes the Z16-17 Zones and probably correlates with the upper part of the Bifrons Zone. Upwards, A13n and A14r are correlated with the base of the Variabilis Zone.

We conclude that for the first time, the Argentine results place portions of the Hettangian-Sinemurian polarity pattern on a firm biostratigraphic basis, although its correlation with the European Standard Zonation remains difficult. In addition, we present the first magnetostratigraphic study that has been completely calibrated with ammonites. During this interval reversed polarity dominated (A1n), which is more consistent with the data from western Austria [6] rather than those of the Paris basin [11]. In the Pliensbachian, the excellent correlation of the Argentina pattern to that of northern Italy [5] represents the first verification of this portion of the MPTS and therefore converts this polarity pattern into a useful time scale. In the Toarcian, the Argentine results confirm the paleomagnetic data obtained by Horner and Heller [5] and significantly improves their part of the MPTS.

\section{Acknowledgements}

H. Vizán, S. Damborenea and M. Manceñido helped in the field. This work was supported by Grants from the Consejo Nacional de Investigaciones Científicas y Técnicas (PIP 4735/96) and the Agencia Nacional de Promoción Científica y Técnica (PICT 1661) of Argentina.[EB]

\section{References}

[1] F.M, Gradstein, F.P Agterberg, J.G. Ogg, J. Hardenbol, P. Van Veen, J. Thierry, Z. Huang, A Triassic, Jurassic and Cretaceous timescale, in: W.A. Bergren, D.V. Kent, M. Aubry, J. Hardenbol (Eds.), Geochronology, Time Scales and Stratigraphic Correlation, SEPM Special Publication 54 (1995) 95-128. 
[2] J.G. Ogg, Mesozoic Magnetic Polarity time scale. International Subcomission on Jurassic Stratigraphy, ISSJ Newslett. 23 (1995) 73-96.

[3] J.G. Ogg, Magnetic Polarity Time Scale of the Phanerozoic, in: Global Earth Physics. A Handbook of Physical Constants, AGU Reference Shelf 1 (1995) 240-270.

[4] G.E.G. Westermann, Gauging the duration of stages a new approach for the Jurassic, Episodes 7 (1984) 26-28.

[5] F. Horner, F. Heller, Lower Jurassic magnetostratigraphy at the Breggia Gorge (Ticino, Switzerland) and Alpi Turati (Como, Italy), Geophys. J. R. Astron. Soc. 73 (1983) 705-718.

[6] M. Steiner, J.G. Ogg, Early and Middle Jurassic Magnetic Polarity Time Scale, in: R. Rocha (Ed.), Proceedings of the 2nd International Symposium on Jurassic Stratigraphy, Lisboa (1988) 1097-1111.

[7] B. Galbrun, J. Gabilly, L. Rasplus, Magnetostratigraphy of the Toarcian stratotype sections at Thouars and Airvault (Deux-Sèvres, France), Earth Planet. Sci. Lett. 87 (1988) 453-462.

[8] B. Galbrun, F. Baudin, E. Fourcade, P. Rivas, Magnetostratigraphy of the Toarcian Ammonitico Rosso limestone at Iznalloz, Spain, Geophys. Res. Lett. 17 (1990) 2441-2444.

[9] W.K. Witte, D.V. Kent, The paleomagnetism of redbeds and basalts of the Hettangian extrusive zone, Newark basin, J. Geophys. Res. 95 (1990) 17533-17546.

[10] D.V. Kent, P.E. Olsen, W.K. Witte, Late Triassic-earliest Jurassic geomagnetic polarity sequence and paleolatitudes from drill cores in the Newark rift basin, eastern North America, J. Geophys. Res. 100 (1995) 14965-14998.

[11] Z. Yang, G. Moreau, H. Bucher, J. Dommergues, A. Trouiller, Hettangian and Sinemurian magnetostratigraphy from Paris Basin, J. Geophys. Res. 101 (1996) 8025-8042.

[12] E. Marton, P. Marton, F. Heller, Remanent magnetization of a Pliensbachian limestone sequence at Bakonycsernye (Hungary), Earth Planet. Sci. Lett. 48 (1980) 218226.

[13] B. Géczy, The Pliensbachian of the Bakony Mountains, Acta Geol. Acad. Sci. Hung. 15 (1971) 117-125.

[14] F. Wiedenmayer, Die Ammoniten der mediterranen Provinz im Pliensbachian und im unteren Toarcian auf grund neuer Untersuchungen im Generoso-Becken (Lombardische Alpen), Denkschr. Schweiz. Nat.forsch. Ges. 93 (1980) 260.

[15] D.T. Donovan, The Ammonite Zones of the Toarcian (Ammonitico Rosso Facies) of southern Switzerland and Italy, Eclogae Geol. Helv. 51 (1958) 33-60.

[16] A.C. Riccardi, S.E. Damborenea, M.O. Manceñido, S.C. Ballent, Hettangian and Sinemurian (Lower Jurassic) biostratigraphy of Argentina, J. South Am. Earth Sci. 4 (1991) 159-170.

[17] A.C. Riccardi, H.A. Leanza, S.E. Damborenea, M.O. Manceñido, S.C. Ballent, Marine Mesozoic Biostratigraphy of the Neuquén Basin, Z. Angew. Geol., in press.

[18] C.A. Gulisano, A. Gutiérrez Pleimling, The Jurassic of the Neuquén Basin. (a) Neuquén Province, Asoc. Geol. Argent. Ser. D 2 (1995) 1-111.

[19] C.A. Gulisano, A. Gutiérrez Pleimling, The Jurassic of the Neuquén Basin. (b) Mendoza Province, Asoc. Geol. Argent. Ser. E 3 (1995) 1-103.

[20] L. Legarreta, M.A. Uliana, The Jurassic succession in west-central Argentina: stratal patterns, sequences and paleogeographic evolution, Paleogeogr. Paleoclimatol. Paleoecol. 120 (1996) 303-330.

[21] A. v. Hillebrandt, Liassic ammonites zones of South America and correlation with other provinces. With description of new genera and species of ammonites, in: W. Volkheimer (Ed.), Bioestratigrafía de los Sistemas regionales del Jurásico y Cretácico de América del Sur, Buenos Aires (1987) 111-157.

[22] A.C. Riccardi, S.E. Damborenea, M.O. Manceñido, Lower Jurassic of South America and Antarctic Peninsula, Newslett. Stratigr. 21 (1990) 75-103.

[23] A.C. Riccardi, C.A. Gulisano, J. Mojica, O. Palacios, C. Schubert, M.R.A. Thomson, Western South America and Antarctica, in: G.E.G. Westermann (Ed.), The Jurassic of the Circum-Pacific, Cambridge University Press, Cambridge (1992) 122-161.

[24] A. v. Hillebrandt, P. Smith, G.E.G. Westermann, J.H. Callomon, Ammonite zones of the circum-Pacific region, in: G.E.G. Westermann (Ed.), The Jurassic of the Circum-Pacific, Cambridge University Press, Cambridge (1992) 247-272.

[25] A.C. Riccardi, M.P. Iglesia Llanos, Primer hallazgo de amonites en el Triásico de la Argentina, Rev. Asoc. Geol. Argent. 54 (1999) 298-300.

[26] A. v. Hillebrandt, Der Untere Jura im Gebiet des Río Atuel (Provinz Mendoza, Argentinien), Neues Jahrb. Geol. Paläontol. Abh. 181 (1990) 143-157.

[27] A. v. Hillebrandt, R. Schmidt-Effing, Ammoniten aus dem Toarcium (Jura) von Chile (Südamerika), Die Arten der Gattungen Dactylioceras, Nodicoeloceras, Peronoceras und Collina, Zitteliana 6 (1981) 3-73.

[28] J.F.A. Vilas, El magnetómetro UBA $8 \mathrm{~Hz}$ y su aplicación en los estudios paleomagnéticos, PH.D thesis, Universidad de Buenos Aires, Buenos Aires, 1979, 80 pp.

[29] J.L. Kirschvink, The least-square line and plane and the analysis of palaeomagnetic data, Geophys. J. R. Astron. Soc. 62 (1980) 699-718.

[30] R.A. Fisher, Dispersion on a sphere, Proc. R. Soc. Lond. Ser. A 217 (1953) 295-306.

[31] P. McFadden, M.W. McElhinny, The combined analysis of remagnetization circles and direct observations in paleomagnetism, Earth Planet. Sci. Lett. 87 (1988) 161-172.

[32] H.C. Halls, A least-squares method to find a remanence direction from converging remagnetization circles, Geophys. J. R. Astron. Soc. 45 (1976) 297-304.

[33] P.L. McFadden, A new fold test for palaeomagnetic studies, Geophys. J. Int. 103 (1990) 163-169.

[34] P.L. McFadden, M.W. McElhinny, Classification of the reversal test in palaeomagnetism, Geophys. J. Int. 103 (1990) 725-729. 
[35] G. Watson, A test for randomness of directions, Mon. Not. R. Astron. Soc. Geophys. 7 (Suppl.) (1956) 160-161.

[36] P. Posen, M.W. Hounslow, G. Warrington, Magnetostratigraphy of the Hettangian-Rhaetian Boundary section, St. Audries Bay, 5th Int. Symp. Jurassic Strat., Vancouver, 1998.
[37] N.D. Opdyke, J.E.T. Channell, Magnetic Stratigraphy, in: R. Dmowska, J.R. Holton (Eds.), International Geophysics Ser. 64, Academic Press, London (1996) 341.

[38] J.E.T. Channell, W. Lowrie, P. Pialli, F. Venturi, Jurassic magnetic stratigraphy from Umbrian (Italian) land sections, Earth Planet. Sci. Lett. 68 (1984) 309-325. 